\title{
Propranolol vs. steroids in the treatment of infantile hemangiomas: A meta-analysis
}

\author{
YITING YOU, YADONG LI, YITING XIAO and JINSONG ZHANG \\ Department of Oral and Maxillofacial Surgery, The First Affiliated Hospital of \\ Chongqing Medical University, Chongqing 400016, P.R. China
}

Received July 5, 2020; Accepted March 3, 2021

DOI: $10.3892 / \mathrm{mco} .2021 .2318$

\begin{abstract}
Infantile hemangioma (IH) is a common disease, and drug therapy is the most common treatment method. Clinically, steroids have long been used as first-line drugs, but in recent years, some doctors have begun to use propranolol to treat infantile hemangiomas (IHs). The present study performed a meta-analysis to evaluate the clinical effects of propranolol in comparison with steroids in the treatment of infantile hemangiomas. A detailed review of the literature on PubMed, Cochrane Library, Embase and Web of Science was performed prior to March 31, 2020. All literatures were compared with the clinical effects of propranolol and steroids in the treatment of infantile hemangiomas. A total of two researchers independently screened the literature according to the selection criteria, extracted data and assessed the risk of bias for the included studies. Review Manager 5.3 was used to meta-analyze all the included studies. According to the selection criteria, nine articles were included in the present study. The meta-analysis revealed that the effective rate of propranolol was greater than that of steroids in treating infantile hemangiomas [odds ratio (OR), 3.96, 95\% confidence interval (CI), 2.47-6.37; $\mathrm{P}<0.00001]$. Additionally, propranolol had fewer complications than steroids (OR, 0.21; 95\% CI, 0.12-0.36; $\mathrm{P}<0.00001)$. The recurrence rate of the two groups was not statistically different (OR, 1.83; 95\% CI, 0.59-5.70; $\mathrm{P}=0.3$ ) and the surgical resection rate of propranolol was lower than steroids (OR, 0.19; 95\% CI, 0.08-0.46; P=0.0002). The present study demonstrated that propranolol is more effective than steroids for the treatment of IHs, and provides a theoretical basis for the clinical use of propranolol as an alternative to steroids.
\end{abstract}

Correspondence to: Professor Jinsong Zhang, Department of Oral and Maxillofacial Surgery, The First Affiliated Hospital of Chongqing Medical University, 1 Youyi Road, Yuzhong, Chongqing 400016, P.R. China

E-mail:21272745@qq.com

Key words: infantile hemangiomas, propranolol, steroid, meta-analysis

\section{Introduction}

Infantile hemangiomas (IHs) are a common type of vascular tumor (1), with an incidence rate ranging from $0.2-10.0 \%$ (2). IHs often occur in the face and neck, and grow rapidly in the first 3-12 months of life, and spontaneously subside at the age of 3-7 years (3). However, in the course of its development, $15 \%$ of children will experience complications that affect their appearance and physiological functions, which can be life-threatening, such as permanent deformities, visual and auditory impairment, local tissue ulcers, bleeding, infection, airway damage (4-6). For untreated hemangiomas, the color and texture of the tumor location is often different from the normal skin after regression, and the majority of children still require surgical repair in adulthood (7). Therefore, active treatment of IHs is necessary, and the sooner the treatment, the better the effect, which can minimize the incidence of complications (8), and also decrease the physical and psychological damage to children and their parents.

In recent years, as the treatment continues to optimize (9), a variety of methods including drug, laser (10) and surgical excision (11) have emerged. However, laser and surgical excision have ulcers, scars, permanent pigmentation and anesthesia risks $(12,13)$, so drug therapy becomes particularly important due to it being less invasive, convenient and economical. Such drugs mainly include vincristine (14), bleomycin (15), interferon (16), steroids (17), propranolol (18). Vincristine is primarily used in patients with life-threatening diseases, or when they have received treatment with other drugs that have proved ineffective (19). Bleomycin was first used in the treatment of cystic lymphangioma in 1977 (20); interferon causes lower limb disability in infants (21). Aforementioned drugs cannot be used as a routine treatment method for IHs. Steroids have been recognized as a first-line drug used for IHs in the past, but there are adverse reactions such as Cushing's syndrome and developmental retardation, which cause irreversible damage to the growth and development of children (22). Therefore, it is particularly important to find a new drug with low side effects and high efficiency.

In 2008, propranolol was first discovered in infantile hemangioma (IH) treatment by Léauté-Labrèze et al (23) when they treated a child with nasal hemangioma and hypertrophic cardiomyopathy, they accidentally found that 
propranolol could relieve the symptoms of hemangioma. They then switched to propranolol for children who did not respond to steroids and achieved good clinical results. Since then, some clinical studies have shown that propranolol also has a certain level of efficacy and safety $(24,25)$. The purpose of the present meta-analysis was to compare the clinical efficacy of propranolol and steroids in the treatment of IHs.

\section{Materials and methods}

Data sources and searches. PubMed, Cochrane Library, Embase and Web of Science databases were searched before date March 31, 2020. The key words used as search terms included 'infantile hemangiomas', 'propranolol', 'steroids', 'steroids' and 'prednisolone'.

Selection criteria. The selection criteria included: i) Published English literature on randomized controlled trials, case-control trials and retrospective studies of propranolol vs. steroids in the treatment of IHs; ii) infants diagnosed with IHs, where hemangioma were located on the body surface, they were $<6$ years of age (26), had no other underlying diseases, had received no other treatment or medication history, and had no limit on race, sex, single or multiple tumors; iii) the following outcome indicators included the number of effective cases, recurrent cases, adverse reactions and surgical resections following drug treatment. Effectiveness is based on the Visual Analogue Scale (VAS) to evaluate color and size: Grade I, poor response (0-25\% regression); Grade II, fair response (26-50\% regression); Grade III, good response (51-75\% regression); and Grade IV, excellent response (76-100\% regression), and $75 \%$ was considered effective (25). The recurrence rate refers to the growth rebound at the time of dose reduction or treatment termination during follow-up.

Literature screening and data extraction. There were two researchers that independently conducted literature screening and data extraction, screened out the literature that did not meet the selection criteria, obtained the full text of the included literature, and after cross-checking, handed over the divergent documents to the third researcher for assistance and decision. Data extraction included author, year of publication, type of study, average age, sex, location of hemangiomas, treatment time, and dose.

Quality assessment. The quality evaluation was conducted by means of methodological index for non-randomized studies (MINORS), with a total of 12 criteria: i) A clearly stated aim; ii) Inclusion of consecutive patients; iiii) Prospective collection of data; iv) Endpoints appropriate to the aim of the study; v) Unbiased assessment of the study endpoint; vi) Follow-up period appropriate to the aim of the study; vii) Loss to follow up less than 5\%; viii) Prospective calculation of the study size; ix) An adequate control group; x) Contemporary groups; xi) Baseline equivalence of groups; xii) Adequate statistical analyses. Each of which received a score of $0-2$. A score of 0 meant that no report had been made; a score of 1 meant that information was reported but insufficient; and a score of 2 meant that sufficient information was reported and provided (27).

Statistical analysis. A meta-analysis was performed on the extracted data with Review Manager 5.3. $\mathrm{Chi}^{2}$ and df are qualitative tests for heterogeneity. When the P-value of $\mathrm{df} \leq 0.05$, it means that the test for heterogeneity is meaningful. $\mathrm{I}^{2}$ is a quantitative test for heterogeneity, if $\mathrm{I}^{2}<50 \%$, it meant that the heterogeneity was acceptable, then the fixed effects model was used for meta-analysis, if $\mathrm{I}^{2} \geq 50 \%$, the factors leading to heterogeneity were analyzed in subgroups. If heterogeneity existed but had no obvious clinical significance, then the random effects model was selected. The odds ratio (OR) and $95 \%$ confidence interval (CI) were used to analyze and count the curative effect indexes. $Z$ represents statistical results, and the $\mathrm{P}$-value of $\mathrm{Z}$ is $\leq 0.05$, indicating that the combined results are statistically significant.

\section{Results}

Literature search and data extraction. A total of 641 articles were obtained after the preliminary retrieval, including the Cochrane Library $(n=8)$, Embase $(n=116)$, PubMed $(n=321)$ and Web of Science $(n=196)$, and two researchers included 28 articles after reading the titles and abstracts. A total of nine of studies were finally included after full-text evaluations of all, including 221 cases of propranolol and 201 cases of steroids (Fig. 1). The full details were extracted (Tables I and II).

Study quality assessment and publication bias evaluation. According to the scoring criteria, 3 studies with scores $>20$ were classified as high quality, 5 studies between 17 and 20 were classified as medium quality, and 1 study $<17$ was classified as low quality (Table III).

In terms of publication bias, the OR value of effectiveness was used as the abscissa and the reciprocal of OR value as the ordinate to draw a funnel diagram. The funnel chart had a symmetrical inverted funnel shape, indicating that the risk of publication bias of the included studies in the present study was small (Fig. 2).

Results of effectiveness. A total of 9 studies were included the present study, including 230 cases of propranolol and 209 cases of steroid. There was no statistically significant heterogeneity test between studies $\left(\mathrm{P}=0.09 ; \mathrm{I}^{2}=41 \%\right)$. The results revealed that the effective rate of propranolol was better than that of steroids, and the difference was statistically significant (OR, 3.96; 95\% CI, 2.47-6.37; P<0.00001; Fig. 3).

Results of recurrence rate. A total of four articles were included, including 138 cases of propranolol and 85 cases of steroids. There was no statistically significant heterogeneity test between studies $\left(\mathrm{P}=0.30 ; \mathrm{I}^{2}=0 \%\right)$. The results revealed that there was no significant difference in the recurrence rate between propranolol and steroid (OR, 1.83; 95\% CI, 0.59-5.70; $\mathrm{P}=0.3$; Fig. 4).

Results of adverse reactions. A total of 8 articles were included, including 204 cases of propranolol and 184 cases of 


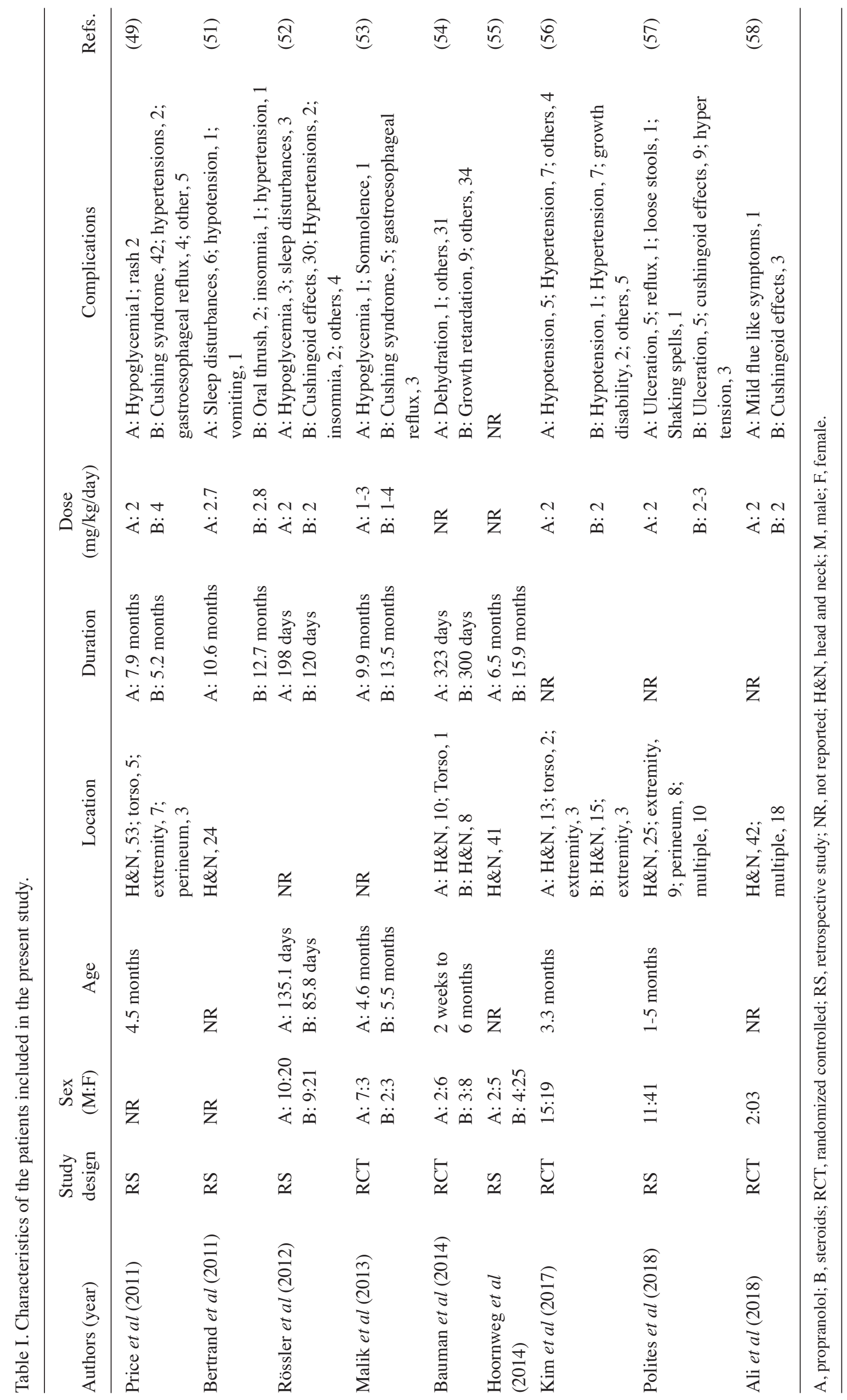


Table II. Statistical results of propranolol vs. steroid therapy for His.

\begin{tabular}{|c|c|c|c|c|c|c|}
\hline Authors (year) & $\begin{array}{c}\text { Total } \\
\text { number }\end{array}$ & $\begin{array}{l}\text { Effective } \\
\text { number }\end{array}$ & $\begin{array}{l}\text { Recurrence } \\
\text { (n) }\end{array}$ & $\begin{array}{c}\text { Adverse } \\
\text { reaction }(n)\end{array}$ & $\begin{array}{c}\text { Surgical } \\
\text { excision (n) }\end{array}$ & Refs. \\
\hline Price et al (2011) & $\begin{array}{l}\text { A: } 68 \\
\text { B: } 42\end{array}$ & $\begin{array}{l}\text { A: } 56 \\
\text { B: } 12\end{array}$ & $\begin{array}{l}\text { A: } 2 \\
\text { B: } 0\end{array}$ & $\begin{array}{l}\text { A: } 3 \\
\text { B: } 14\end{array}$ & $\begin{array}{l}\text { A: } 8 \\
\text { B: } 12\end{array}$ & (49) \\
\hline Bertrand et al (2011) & $\begin{array}{l}\text { A: } 12 \\
\text { B: } 12\end{array}$ & $\begin{array}{l}\text { A: } 12 \\
\text { B: } 9\end{array}$ & NR & $\begin{array}{l}\text { A: } 2 \\
\text { B: } 7\end{array}$ & NR & $(51)$ \\
\hline Rossler et al (2012) & $\begin{array}{l}\text { A: } 39 \\
\text { B: } 38\end{array}$ & $\begin{array}{l}\text { A: } 25 \\
\text { B: } 23\end{array}$ & $\begin{array}{l}\text { A: } 5 \\
\text { B: } 3\end{array}$ & $\begin{array}{l}\text { A: } 6 \\
\text { B: } 9\end{array}$ & NR & $(52)$ \\
\hline Malik et al (2013) & $\begin{array}{l}\text { A: } 10 \\
\text { B: } 10\end{array}$ & $\begin{array}{l}\text { A: } 10 \\
\text { B: } 9\end{array}$ & NR & $\begin{array}{l}\text { A: } 2 \\
\text { B: } 9\end{array}$ & NR & $(53)$ \\
\hline Bauman et al (2014) & $\begin{array}{l}\text { A: } 11 \\
\text { B: } 8\end{array}$ & $\begin{array}{l}\text { A: } 7 \\
\text { B: } 23\end{array}$ & $\begin{array}{l}\text { A: } 2 \\
\text { B: } 1\end{array}$ & $\begin{array}{l}\text { A: } 9 \\
\text { B: } 7\end{array}$ & NR & $(54)$ \\
\hline $\begin{array}{l}\text { Hoornweg et al } \\
\text { (2014) }\end{array}$ & $\begin{array}{l}\text { A: } 14 \\
\text { B: } 29\end{array}$ & $\begin{array}{l}\text { A: } 14 \\
\text { B: } 21\end{array}$ & NR & $\begin{array}{l}\text { A: } 0 \\
\text { B: } 16\end{array}$ & $\begin{array}{l}\text { A: } 0 \\
\text { B: } 10\end{array}$ & $(55)$ \\
\hline Kim et al (2017) & $\begin{array}{l}\text { A: } 17 \\
\text { B: } 17\end{array}$ & $\begin{array}{l}\text { A: } 17 \\
\text { B: } 15\end{array}$ & NR & NR & NR & $(56)$ \\
\hline Polites et al (2018) & $\begin{array}{l}\text { A: } 29 \\
\text { B: } 23\end{array}$ & $\begin{array}{l}\text { A: } 27 \\
\text { B: } 17\end{array}$ & $\begin{array}{l}\text { A: } 1 \\
\text { B: } 0\end{array}$ & $\begin{array}{l}\text { A: } 7 \\
\text { B: } 10\end{array}$ & NR & $(57)$ \\
\hline Ali et al (2018) & $\begin{array}{l}\text { A: } 30 \\
\text { B: } 30\end{array}$ & $\begin{array}{l}\text { A: } 25 \\
\text { B: } 20\end{array}$ & NR & $\begin{array}{l}\text { A: } 1 \\
\text { B: } 3\end{array}$ & NR & $(58)$ \\
\hline
\end{tabular}

A, propranolol treatment group; B, steroid treatment group. NR, not reported.

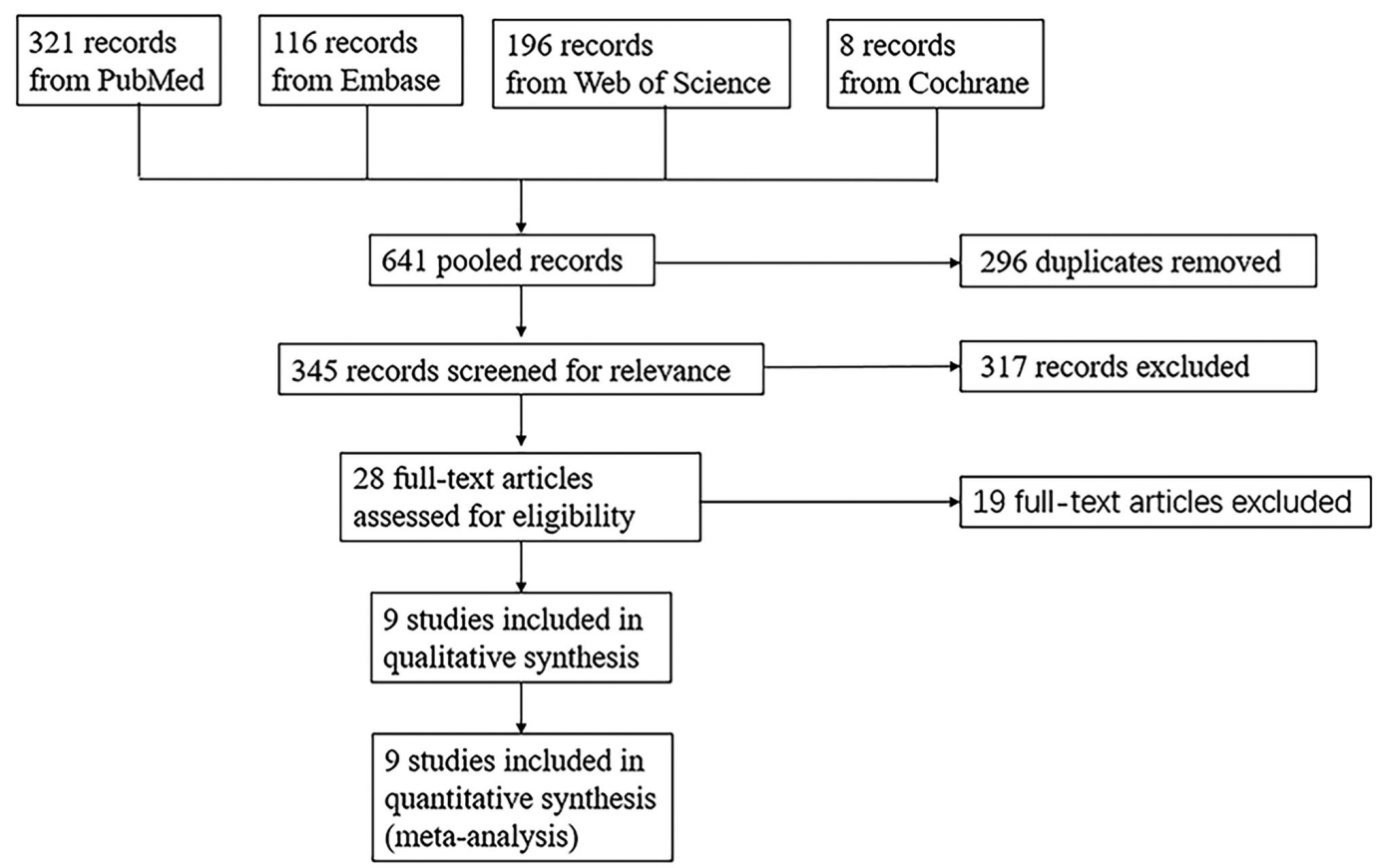

Figure 1. Flow diagram of study selection. A total of 641 literatures were retrieved, and nine literatures were finally included after screening.

steroids. There was no statistically significant heterogeneity test between the studies $\left(\mathrm{P}=0.15 ; \mathrm{I}^{2}=35 \%\right)$. The results revealed that the incidence of adverse reactions of propranolol was lower than that of the steroid group, which was statistically significant (OR, 0.21; 95\% CI, 0.12-0.36; P<0.00001; Fig. 5).
Results of surgical resection rate. A total of two articles were included, including 82 cases of propranolol and 56 cases of steroids. There was no statistically significant heterogeneity test between studies $\left(\mathrm{P}=0.05 ; \mathrm{I}^{2}=74 \%\right)$. The results revealed that the surgical resection rate of propranolol was lower than 


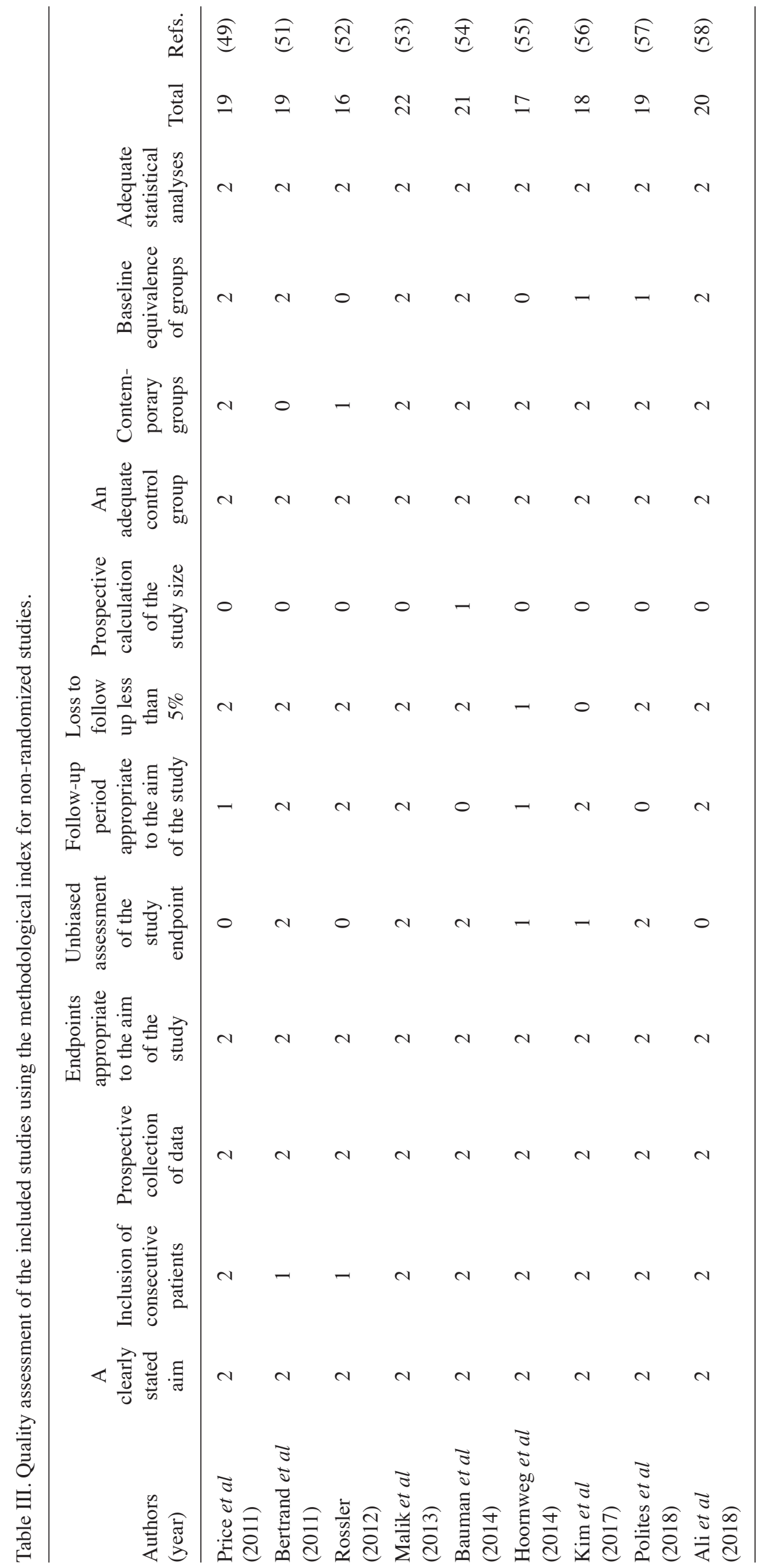




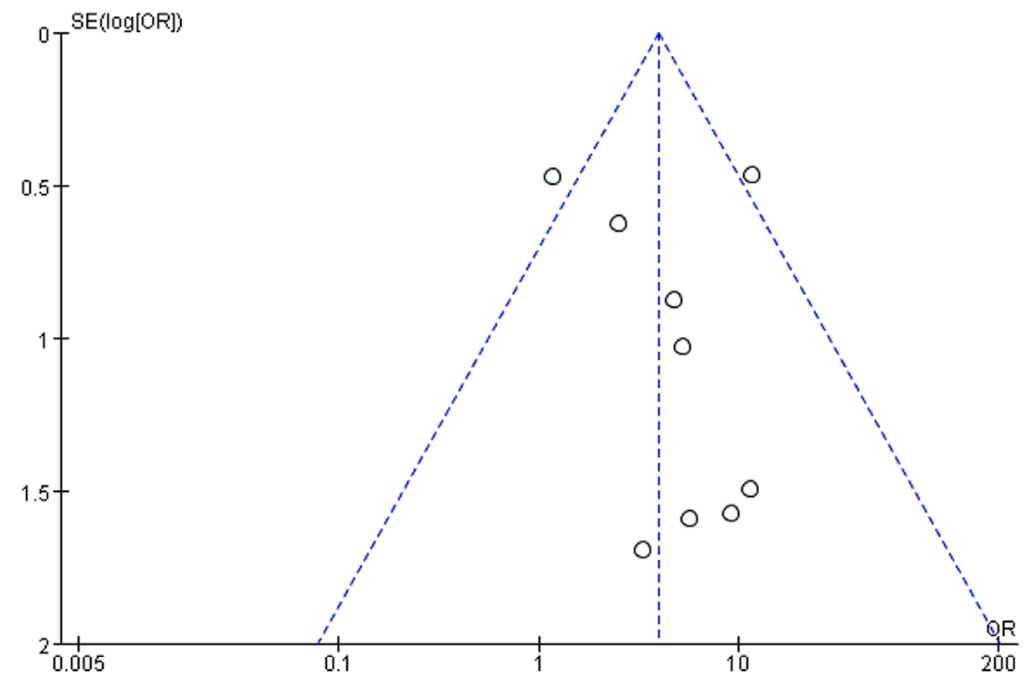

Figure 2. Funnel plot for publication bias evaluation. Circles represent the included studies. The funnel plot is symmetric, indicating that the risk of bias was small. OR, odds ratio; SE, standard error.

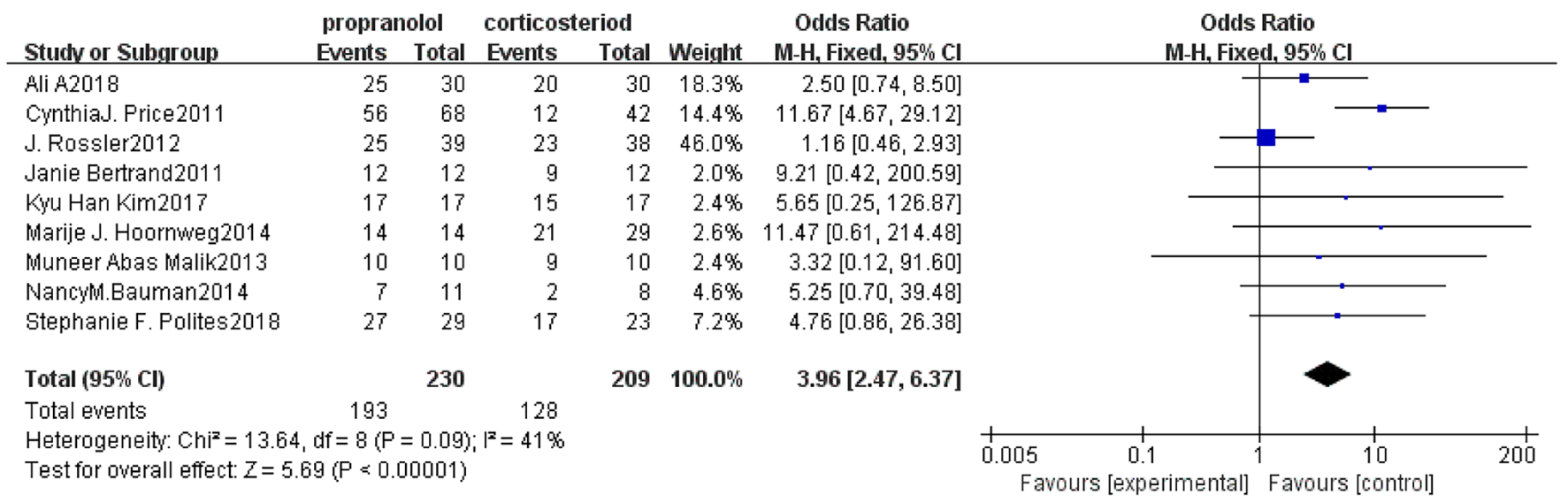

Figure 3. Meta-analysis of effective rate. CI, confidence interval.

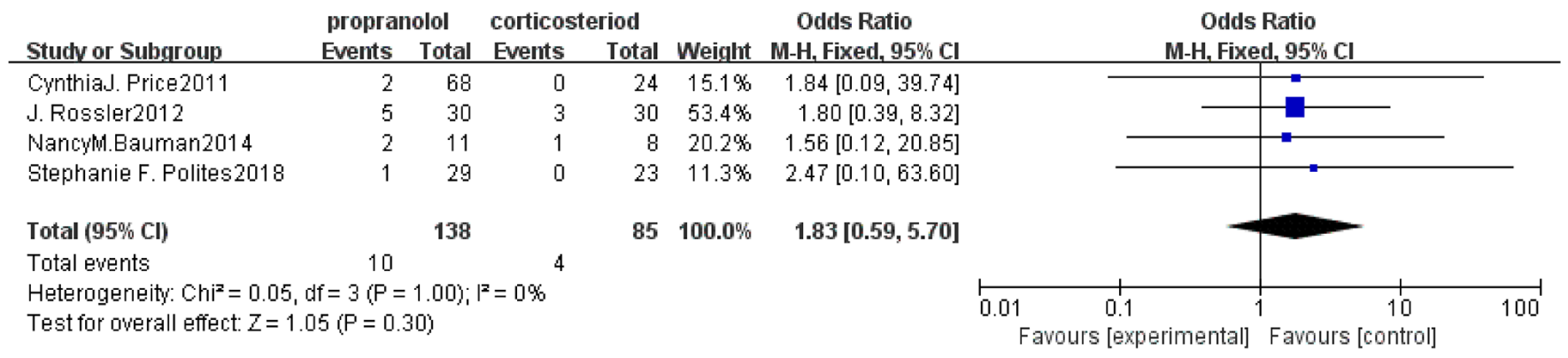

Figure 4. Meta-analysis of recurrence rate. CI, confidence interval.

that of steroid, and the difference was statistically significant (OR, 0.19; 95\% CI, 0.08-0.46; P=0.0002; Fig. 6).

\section{Discussion}

IHs are a complex mixture of clonal endothelial cells associated with epidermal, dendritic and mast cells (28). Of IHs, $>10 \%$ can cause upper airway obstruction (29), ulcers, bleeding, soft tissue malformations and high-output heart failure (30). Vascular endothelial growth factor (VEGF) and basic fibroblast growth factor (bFGF) can regulate the growth of IHs (31). Steroids mainly act on the proliferation stage of IHs by inhibiting the expression levels of immature VEGF and bFGF, which blocks angiogenesis and prevents the growth of the tumor body (32-34). In addition, estrogen serves a role in the growth of IHs (35), and thus, steroids may be able to bind to estrogen receptors, thereby reducing the effects of estrogen and ultimately inhibiting hemangioma growth. 


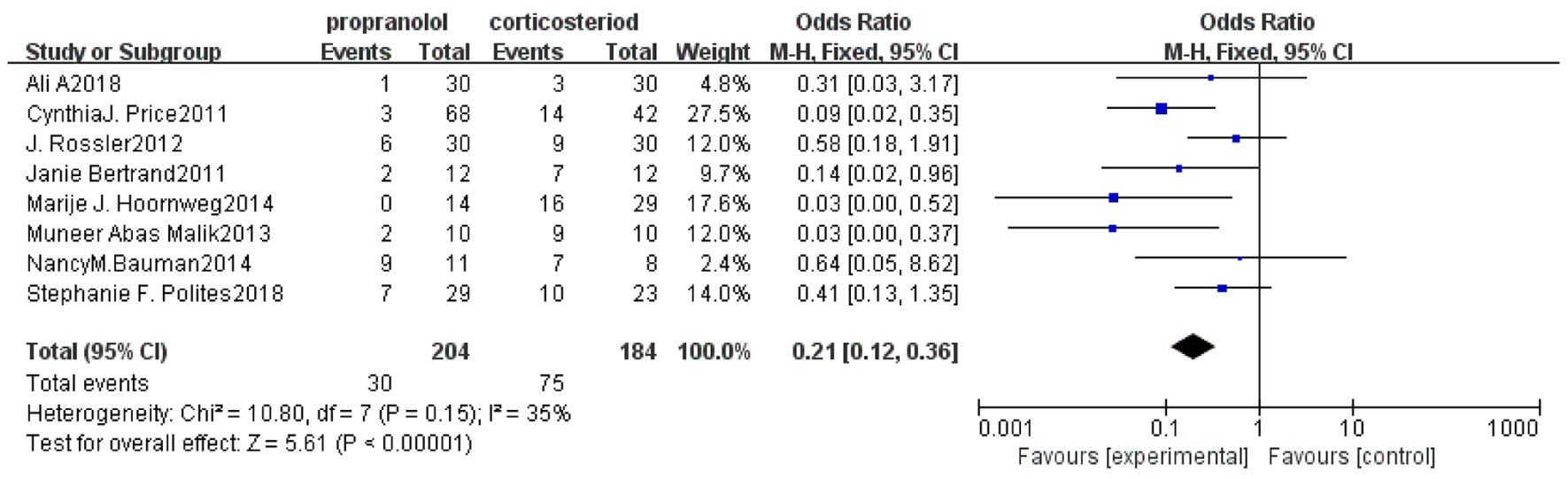

Figure 5. Meta-analysis of incidence of adverse reactions. CI, confidence interval.

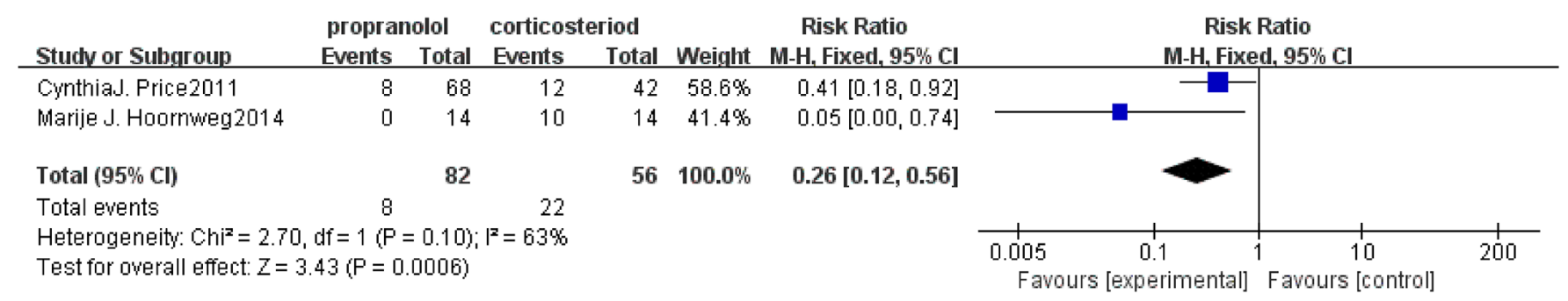

Figure 6. Meta-analysis of surgical resection rate. CI, confidence interval.

The effectiveness of steroid therapy is $\sim 78 \%$ (36); however, long-term use often causes serious side effects. The majority of children will have obvious cushings-like changes (37), and certain patients will have behavior changes (such as irritability or insomnia), high blood pressure, gastrointestinal irritation, fungal infections and may even influence height development (38). The effectiveness of propranolol is $\sim 88 \%$ for the treatment of IHs (36). In the short term, propranolol mainly acts on beta receptors on capillary endothelial cells, resulting in the receptor being unable to bind with adrenaline, and thus inhibits vasodilation (39). Moreover, propranolol can increase the constriction of hemangioma pericytes and further contracts the blood vessels (40). The role of propranolol in the medium term is major mainly inhibits cell proliferation and angiogenesis by blocking the relevant regulatory factors and signaling pathways of angiogenesis, including blocking the mitogen that activates the protein kinase pathway (Rac/MAPK) (41), blocking the PI3K signaling pathway (42), reducing hypoxia inducible factor 1 (43) and blocking DLL4/Notch1Akt signaling (44). At the same time, propranolol can decrease the synthesis and release of NO, inhibit vascular smooth muscle relaxation, and cause hemangioma vasoconstriction (45). The long-term effect of propranolol is to induce endothelial cell apoptosis, mainly by reducing the expression levels of STAT3 and the anti-apoptotic protein $\mathrm{Bcl} 2$ (44), whilst promoting the expression levels of the apoptotic proteins caspase-3, -8 and -9 (46) and the tumor suppressor gene p53 (47). Studies have shown that when the therapeutic dose of propranolol is $\geq 2 \mathrm{mg} / \mathrm{kg} / \mathrm{day}$, a better therapeutic effect can be obtained (48).

A total of 9 controlled experiments were included in the present study, among which 221 patients received propranolol and 201 patients received steroids. The results of the meta-analysis of the 9 groups showed that propranolol had a higher efficacy and less adverse reactions than steroids in the treatment of IHs. Adverse reactions to propranolol occurred in 30 patients, including asymptomatic hypotension, vomiting and non-specific rash, but in some children the symptoms were completely reversible after drug withdrawal. Adverse reactions to steroids occurred in 75 patients, including Cushings-like changes, oral sores, irritability, insomnia, arterial hypertension, arterial hemorrhage, gastroesophageal reflux, hypertrichosis, dysplasia, hypercholesterolemia. There was no significant difference in the recurrence rate between the two; propranolol was also lower than steroids in the rate of surgical resection due to poor therapeutic effect or unsatisfactory aesthetic recovery. Meanwhile, Price et al (49) found that propranolol costs about half as much as steroids. As propranolol has higher efficacy and safety levels than steroids, it may replace steroids as a new first-line therapeutic drug (50).

There were three limitations to the present study. First, there is a small number of literatures included in the present study, and there are not enough randomized controlled trials, so there is a certain selectivity bias. Secondly, due to the lack of analysis of different sites of IHs in the included literature, the occurrence sites of hemangioma could not be studied separately, and the sensitivity of different sites of IHs to the two drugs could not be proved to be different. Thirdly, for children with complications, there is a lack of long-term follow-up to observe whether the complications have completely disappeared, as well as the recovery time after drug withdrawal, so it is impossible to more fully evaluate the long-term effects and harms of propranolol on children.

In summary, the present study proves that propranolol has better clinical efficacy and lower complications than steroids for the treatment of IHs, and provides a certain theoretical 
basis for the selection of treatment schemes for IHs. However, more high-quality randomized controlled trials are needed to strengthen the evidence. At the same time, the mechanism underlying propranolol on IHs still needs further study.

\section{Acknowledgements}

Not applicable.

\section{Funding}

No funding was received.

\section{Availability of data and materials}

The datasets used and/or analyzed during the present study are available from the corresponding author on reasonable request.

\section{Authors' contributions}

JZ and YY designed the study and drafted the manuscript. YY, YL and YX participated in study screening, data extraction and statistics. YL and JZ were involved in result validation and quality assessment. JZ and YY confirm the authenticity of all the raw data. All authors contributed to revising the manuscript and all authors read and approved the final manuscript.

\section{Ethics approval and consent to participate}

Not applicable.

\section{Patient consent for publication}

Not applicable.

\section{Competing interests}

The authors declare that they have no competing interests.

\section{References}

1. Aizman L, Van Den Anker J, Tender J, Krishnan A and Kirkorian AY: Special management considerations for propranolol use in breastfed infants of mothers taking antihypertensives. Pediatr Dermatol 37: 537-540, 2020.

2. Munden A, Butschek R, Tom WL, Marshall JS, Poeltler DM, Krohne SE, Alió AB, Ritter M,Friedlander DF, Catanzarite V, et al: Prospective study of infantile haemangiomas: Incidence, clinical characteristics and association with placental anomalies. Br J Dermatol 170: 907-913, 2014.

3. Maguiness SM: Vascular tumors and malformations in children, introduction. Semin Cutan Med Surg 35: 107, 2016.

4. Howard MA, Olitsky SE, Rychwalski P and Mungan N: Management of periocular infantile hemangioma. J Pediatr Ophthalmol Strabismus 56: 344-346, 2019.

5. Léauté-Labrèze C, Harper JI and Hoeger PH: Infantile haemangioma. Lancet 390: 85-94, 2017.

6. Yuzuriha S, Nagai F and Noguchi M: How to manage disfiguring scars in involuted infantile hemangioma. Adv Wound Care (New Rochelle) 8: 221-229, 2019.

7. Hochman M: The role of surgery in the management of infantile hemangiomas: What is the best timing? Otolaryngol Clin North Am 51: 119-123, 2018.

8. Zhang L, Wu HW, Yuan W and Zheng JW: Propranolol therapy for infantile hemangioma: Our experience. Drug Des Devel Ther 11: 1401-1408, 2017.
9. Chen ZY, Wang QN, Zhu YH, Zhou LY, Xu T, He ZY and Yang Y: Progress in the treatment of infantile hemangioma. Ann Transl Med 7: 692, 2019.

10. Chinnadurai S, Sathe NA and Surawicz T: Laser treatment of infantile hemangioma: A systematic review. Lasers Surg Med 48: 221-233, 2016.

11. Leone F, Benanti E, Marchesi A Marcelli S, Gazzola R and Vaienti L: Surgical excision of infantile hemangiomas: A technical refinement to prevent bleeding complications. J Pediatr Med Chir 36: 7, 2014.

12. Kagami S, Kuwano Y, Shibata S, Uwajima Y, Yamada D, Miyamoto A, Miyagawa T, Araki M, Takahashi K, Isomura S, et al: Propranolol is more effective than pulsed dye laser and cryosurgery for infantile hemangiomas. Eur J Pediatr 172: 1521-1526, 2013.

13. Satterfield KR and Chambers CB: Current treatment and management of infantile hemangiomas. Surv Ophthalmol 64: 608-618, 2019.

14. Techasatian L and Phukam N: Treatment modalities and outcomes of infantile hemangiomas at srinagarind hospital. J Med Assoc Thai 99 (Suppl 5): S74-S80, 2016.

15. Qiu Y, Lin X, Ma G, Chang L, Jin Y, Chen H and Hu X: Eighteen cases of soft tissue atrophy after intralesional bleomycin a5 injections for the treatment of infantile hemangiomas: A long-term follow-up. Pediatr Dermatol 32: 188-191, 2015.

16. White CW, Sondheimer HM, Crouch EC, Wilson H and Fan LL: Treatment of pulmonary hemangiomatosis with recombinant interferon alfa-2a. N Engl J Med 320: 1197-1200, 1989.

17. Chai Y, Zhou Z, Song J, Lv R, Xu G, Bi J, Li X, Li Z and Huo R: Safety of ntralesional injection of lauromacrogol combined with triamcinolone for infantile hemangiomas. J Dermatol 46: 770-776, 2019.

18. Sinha S and Lloyd MS: Propranolol for surgeons in the treatment of infantile hemangiomas. J Craniofac Surg 31: 134-137, 2020.

19. Wasserman JD, Mahant S, Carcao M, Perlman K and Pope E: Vincristine for successful treatment of steroid-dependent infantile hemangiomas. Pediatrics 135: e1501-e1505, 2015.

20. Düzenli Kar Y, Özdemir ZC, Acu B and Bör Ö: Infantile hemangioma: Efficacy of low-dose propranolol and of intralesional bleomycin injection for propranolol non-response. Pediatr Int 61: 459-464, 2019.

21. Zhang L, Zheng JW and Yuan WE: Treatment of alarming head and neck infantile hemangiomas with interferon- $\alpha 2 \mathrm{a}$ : A clinical study in eleven consecutive patients. Drug Des Devel Ther 9: 723-727, 2015.

22. Soliman YS and Khachemoune A: Infantile hemangiomas: Our current understanding and treatment options. Dermatol Online J 24: 13030/qt5jt8q9km, 2018.

23. Léauté-Labrèze C, Dumas de la Roque E, Hubiche T, Boralevi F, Thambo JB and Taïeb A: Propranolol for severe hemangiomas of infancy. N Engl J Med 358: 2649-2651, 2008.

24. Kado M, Shimizu A, Matsumura T, Mochizuki M, Mizuno H and Hayashi A: Successful treatment of infantile hemangiomas with propranolol in low-birth-weight infants. J Craniofac Surg 28: 789-793, 2017.

25. Ainipully AM, Narayanan SK, Vazhiyodan AP and Somnath P: Oral propranolol in infantile hemangiomas: Analysis of factors that affect the outcome. J Indian Assoc Pediatr Surg 24: 170-175, 2019.

26. Polites SF, Watanabe M,CraftonT,Jenkins TM,Alvarez-Allende CR, Hammill AM and Dasgupta R: Surgical resection of infantile hemangiomas following medical treatment with propranolol vs. corticosteroids. J Pediatr Surg 54: 740-743, 2019.

27. Slim K, Nini E, Forestier D, Kwiatkowski F, Panis Y and Chipponi J: Methodological index for non-randomized studies (minors): Development and validation of a new instrument. ANZ J Surg 73: 712-716, 2003.

28. Frieden IJ, Haggstrom AN, Drolet BA, Mancini AJ, Friedlander SF, Boon L, Chamlin SL, Baselga E, Garzon MC, Nopper AJ, et al: Infantile hemangiomas: Current knowledge, future directions. Proceedings of a research workshop on infantile hemangiomas, April 7-9, 2005, Bethesda, Maryland, USA. Pediatr Dermatol 22: 383-406, 2005.

29. Darrow DH: Management of infantile hemangiomas of the airway. Otolaryngol Clin North Am 51: 133-146, 2018.

30. Blei F and Guarini A: Current workup and therapy of infantile hemangiomas. Clin Dermatol 32: 459-470, 2014.

31. Ozeki M, Nozawa A, Hori T, Kanda K, Kimura T, Kawamoto N and Fukao T: Propranolol for infantile hemangioma: Effect on plasma vascular endothelial growth factor. Pediatr Int 58: 1130-1135, 2016. 
32. Khan ZA, Boscolo E, Picard A, Psutka S, Melero-Martin JM, Bartch TC, Mulliken JB and Bischoff J: Multipotential stem cells recapitulate human infantile hemangioma in immunodeficient mice. J Clin Invest 118: 2592-2599, 2008.

33. Greenberger S, Boscolo E, Adini I, Mulliken JB and Bischoff J: Corticosteroid suppression of VEGF-A in infantile hemangioma-derived stem cells. N Engl J Med 362: 1005-1013, 2010.

34. Matsuda S, Gomi F, Oshima Y, Tohyama M and Tano Y: Vascular endothelial growth factor reduced and connective tissue growth factor induced by triamcinolone in ARPE19 cells under oxidative stress. Invest Ophthalmol Vis Sci 46: 1062-1068, 2005.

35. Zhang L, Wu HW, Yuan W and Zheng JW: Estrogen-mediated hemangioma-derived stem cells through estrogen receptor- $\alpha$ for infantile hemangioma. Cancer Manag Res 9: 279-286, 2017.

36. Liu X, Qu X, Zheng J and Zhang L: Effectiveness and safety of oral propranolol vs. other treatments for infantile hemangiomas: A meta-analysis. PLoS One 10: e0138100, 2015.

37. Bota M, Popa G, Blag C and Tataru A: Infantile hemangioma: A brief review. Clujul Med 88: 23-27, 2015.

38. Sethuraman G, Yenamandra VK and Gupta V: Management of infantile hemangiomas: Current trends. J Cutan Aesthet Surg 7: 75-85, 2014

39. Cavalli R, Buffon RB, de Souza M, Colli AM and Gelmetti C: Tumor lysis syndrome after propranolol therapy in ulcerative infantile hemangioma: Rare complication or incidental finding? Dermatology 224: 106-109, 2012.

40. Lee D, Boscolo E, Durham JT, Mulliken JB, Herman IM and Bischoff J: Propranolol targets the contractility of infantile haemangioma-derived pericytes. Br J Dermatol 171: 1129-1137, 2014.

41. Storch $\mathrm{CH}$ and Hoeger PH: Propranolol for infantile haemangiomas: Insights into the molecular mechanisms of action. $\mathrm{Br} J$ Dermatol 163: 269-274, 2010

42. Pan WK, Li P, Guo ZT, Huang Q and Gao Y: Propranolol induces regression of hemangioma cells via the down-regulation of the PI3K/Akt/ eNOS/VEGF pathway. Pediatr Blood Cancer 62: $1414-1420,2015$.

43. de Jong S, Itinteang T, Withers AH, Davis PF and Tan ST: Does hypoxia play a role in infantile hemangioma? Arch Dermatol Res 308: 219-227, 2016.

44. Sun B, Dong C, Lei H, Gong Y, Li M, Zhang Y, Zhang H and Sun L: Propranolol inhibits proliferation and invasion of hemangioma-derived endothelial cells by suppressing the DLL4/Notch1/Akt pathway. Chem Biol Interact 294: 28-33, 2018

45. Sharifpanah F, Saliu F, Bekhite MM, Wartenberg M and Sauer H: $\beta$-Adrenergic receptor antagonists inhibit vasculogenesis of embryonic stem cells by downregulation of nitric oxide generation and interference with VEGF signalling. Cell Tissue Res 358: 443-452, 2014

46. England RW, Hardy KL, Kitajewski AM, Wong A, Kitajewski JK, Shawber CJ and Wu JK: Propranolol promotes accelerated and dysregulated adipogenesis in hemangioma stem cells. Ann Plast Surg 73 (Suppl 1): S119-S124, 2014.
47. Yao TH, Pataer P, Regmi KP, Gu XW, Li QY, Du JT, Ge SM and Tu JB: Propranolol induces hemangioma endothelial cell apoptosis via a p53-BAX mediated pathway. Mol Med Rep 18: 684-694, 2018

48. Yang H, Hu DL, Shu Q and Guo XD: Efficacy and adverse effects of oral propranolol in infantile hemangioma: A meta-analysis of comparative studies. World J Pediatr 15: 546-558, 2019.

49. Price CJ, Lattouf C, Baum B, McLeod M, Schachner LA, Duarte AM and Connelly EA: Propranolol vs. corticosteroids for infantile hemangiomas: A multicenter retrospective analysis. Arch Dermatol 147: 1371-1376, 2011.

50. Lie E and Püttgen KB: Corticosteroids as an adjunct to propranolol for infantile haemangiomas complicated by recalcitrant ulceration. Br J Dermatol 176: 1064-1067, 2017.

51. Bertrand J, McCuaig C, Dubois J, Hatami A, Ondrejchak S, Powell J: Propranolol versus prednisone in the treatment of infantile hemangiomas: a retrospective comparative study. Pediatr Dermatol 28: 649-654, 2011.

52. Rössler J, Schill T, Bähr A, Truckenmüller W, Noellke P, and Niemeyer C: Propranolol for proliferating infantile haemangioma is superior to corticosteroid therapy-A retrospective, single centre study. J Eur Acad Dermatol Venereol 26: 1173-1175, 2012.

53. Malik MA, Menon P, Rao KLN, and Samujh R: Effect of propranolol vs prednisolone vs propranolol with prednisolone in the management of infantile hemangioma: a randomized controlled study. J Pediatr Surg 48: 2453-2459, 2013.

54. Bauman NM, McCarter RJ, Guzzetta PC, Shin JJ, Oh AK, Preciado DA, He J, Greene EA, Puttgen KB: Propranolol vs prednisolone for symptomatic proliferating infantile hemangiomas: a randomized clinical trial. JAMA Otolaryngol Head Neck Surg 140: 323-330, 2014.

55. Hoornweg MJ, Saeed P, Tanck MW, Hage JJ, Coumou AD, Van Der Horst CMAM: Comparison of intralesional corticosteroid and propranolol treatment of periorbital infantile hemangiomas: an outcome study of 61 cases. Eur J Ophthalmol 24: 940-947, 2014

56. Kim KH, Choi TH, Choi Y, Park YW, Hong KY, Kim DY, Choe YS, Lee H, Cheon J-E , Park J, et al: Comparison of efficacy and safety between propranolol and steroid for infantile hemangioma: A randomized clinical trial. JAMA Dermatol 153: 529-536, 2017.

57. Polites SF, Rodrigue BB, Chute C, Hammill A, Dasgupta R: Propranolol versus steroids for the treatment of ulcerated infantile hemangiomas. Pediatr Blood Cancer 65: e27280, 2018.

58. Ali A, Aiman U, Haseen MA, Mir MA, Imran G, Bharadwaj R, Yaseen M: The effect of oral propranolol versus oral corticosteroids in management of pediatric hemangiomas. World J Plast Surg 7:16-24, 2018 